Article

\title{
Developing salinity tolerate trees for challenging sites and ur- ban forests based on the inferences of physiological responses: using Ulmus pumila as an example
}

\author{
Deyu $\mathrm{Mu}^{1 *}$ and Chen Ding ${ }^{2 *}$ \\ 1 School of Art, Shandong Jianzhu University, Jinan, Shandong, China, 250000; dmu@ualberta.ca \\ 2 Western Gulf Forest Tree Improvement Program, Texas A\&M Forest Service, Building 1042 Agronomy Road, \\ TAMU 2585, College Station, TX, 77843-2585, USA; cd2@ualberta.ca \\ * Correspondence: DM, dmu@ualberta.ca; CD, cd2@ualberta.ca;
}

\begin{abstract}
Elevated salinity is one of the major environmental limitation factors of plant growth and development and salinity stress compromises the production and survival of plantation and urban forests and agricultural crops in the arid, semi-arid, and intertidal zones. Ulmus pumila, a salt- indigenous tree species in Asia and is widely deployed in salt-affected areas in China, and U.pumila is promising for multi-varietal forestry in plantation and urban forests. The comprehensive mechanism of the intraspecific salt tolerance is still not clear yet. Here, we investigated the physiological responses of the salinity stress based on the antioxidant enzyme activities, osmotic adjustments, and gas exchange among salt-tolerant $U$. pumila genotypes for 100 days under five different $\mathrm{NaCl}$ levels $(0 \%, 0.3 \%, 0.5 \%, 0.7 \%$, and $0.9 \% \mathrm{w} / \mathrm{v})$ with natural surroundings and rain shade at age- 2 . Salt stress decreased height (HR), ground diameter (DR), and dry weight (biomass) were significantly different among genotypes. HR and performance indices were positively correlated with photosynthesis rate (Pn), apparent mesophyll conductance (AMC), and chlorophyll (CHLL) with $\left(\mathrm{r}=0.7-0.8^{* * *}\right)$, but were negatively related to the free proline, sugar, and protein accumulation $\left(\mathrm{r}=-0.5 \sim-0.7^{* * *}\right)$. We found that high accumulation of sugars and more activities of SOD enzyme in leaf tissue contribute to the osmotic adjustment and ROS scavenging system under salinity treatment; the sugar content and SOD activity play key roles in $U$. pumila's tolerance to salt stress, and are promising indicators for $U$. pumila species ex vitro selections. The ex vitro selection results align with the previous in vitro studies [37] and is promising for the MVF development.
\end{abstract}

Keywords: keyword 1; Ulmus pumila 2; salt stress 3; salt-tolerance 4; antioxidants 5; osmolytes 6; gasexchange

\section{Introduction}

The global forestry sectors are facing multiple challenges in plantations such as the increasing demand for wood and fibre with high quality from shrinking forestland, emerging ecological and social risks due to climate change and deforestation [1]; plantation is more necessary at challenging sites for water soil conservation, land reclamation, carbon sequestration [2,3]; urban forests with climate and salinity stress-tolerated tree varieties are popular in municipalities especially for de-icing salt using cities [4-6]. Multi-varietal forestry (MVF) employs selected tree genotypes with desirable merits of commercial traits for operational scale production, which is built upon the sophisticated vegetative propagation techniques [7]. Urban forestry also adopted varietal deployment (e.g., vegetative reproduction) for horticultural application. In broad-leaf trees such as elms, MVF is promising as the result of the tissue culture and somatic embryogenesis technology for the landscape-scale deployment of elite varieties that are tolerant to abiotic stresses such as salinity [37]. MVF also enables the tree variety production from ex vitro selection for urban forest development. 
Soil salinity is a major abiotic stress factor challenges agriculture production and afforestation for long-term [8], and 99\% of the world's flora cannot survive at such high salt surroundings [9]. Previous studies showed that $10 \%$ of the land area has been frequently affected by salinity worldwide, which included approx. $20 \%$ of the world's irrigated land with significant crop yield losses [10,11]. Forests suffered from productivity losses due to high soil salinity in China [12], Canada [13], Australia [14], etc. Salinity tolerance of trees and crop varieties is necessary for restore the forest landscape and carbon sequestration $[14,15]$. The salt-tolerate plants that survive to reproduce in environments where the $\mathrm{NaCl}$ over $200 \mathrm{mM}$ are called halophytes [16]. Excessive salinity (i.e., $>40 \mathrm{mM} \mathrm{NaCl}$ ) in the soil will affect the growth and development of most plants $[17,18]$.

A series of physiological and biochemical changes are involved during the plants' response to salt stress at the cell and tissue levels: osmotic stress, ionic stress, and oxidative stress; and these are the three main factors affecting the plants exposed to salinity $[19,20]$. Salinity stress imposes osmotic stresses and causes osmotic adjustment by the accumulation of osmotic regulation substances such as proline, sugar, and protein [21]. Salinity also causes the increasing reactive oxygen species (ROS), such as superoxide radicals $\left(\mathrm{O}_{2}{ }^{-}\right)$, hydrogen peroxide $\left(\mathrm{H}_{2} \mathrm{O}_{2}\right)$, and hydroxyl radicals $\left(\mathrm{OH}^{-}\right)[22,23]$. To scavenge ROS, antioxidant enzymes such as superoxide dismutase (SOD), catalase (CAT), and peroxidase (POD) neutralize the free radicals and reduce the potential cell damage caused by the oxidative stress [24,25]. For the whole individual plant, salinity stress will alter the ion homeostasis and cause an increase in $\mathrm{Na}^{+}$and $\mathrm{Cl}^{-}$concentration and a decrease in $\mathrm{K}^{+}, \mathrm{Ca}^{2+}$, and $\mathrm{N}^{3+}$ content [26-28]. Salt accumulation damages the photosynthetic leaves while increasing the senescence rate [29]. For different plant species, several physiological responses to salinity qualitatively or quantitatively differentiate among the salt-tolerant and sensitive species or lines [30,31]. In purslane (Portulaca oleracea) and wheat (Triticum aestivum), the proline is an essential indicator that highly accumulated in salt-tolerant than in salt-sensitive cultivars [32,33]. While, opposite results were reported in Acacia spp. and Sorghum bicolor, and showed that the high accumulation of proline in leaves is not a key salt-tolerant indicator in these plants [31,34]. Similar results were also reported in different physiological reactions, such as antioxidant enzymes, soluble sugars, and amino acids $[35,36]$. Thus, the strategies of salt-resistant in plants were species-dependent that need to be studied in separate cases.

Siberian elm (Ulmus pumila L.) is an indigenous tree species to Asia and has often been considered for forest plantations in salt-affected areas in China due to its high resistance to drought, extreme temperatures, and salinity [37]. Thus, U. pumila plays an essential role in promoting revegetation and reducing wind erosion in the arid sandy $[38,39]$ and steppe area [40,41]. Previous studies of $U$. pumila focused on the genetics and breeding due to its high tolerance to the Dutch elm disease [42-46]. More recently, the studies of programmed cell death and reactive oxygen species have been reported in $U$. pumila seeds [47-49]. The effect of salinity on Siberian elm has only been reported on the seedlings responses in photosynthetic characteristics in sand culture [50] and the activity of superoxide dismutase in leaves [51]. However, little is known about the physiological mechanism of salt-tolerant tissue-cultured Ulmus pumila under salt stress.

Our primary objectives of this study were to i) determine the salt effect on ex vitro of Siberian elm under nature surroundings, ii) find out the physiological salt-resistant strategy of $U$. pumila by comparing the different response mechanism between salt-tolerant and salt-sensitive $U$. pumila seedlings in the context of MVF. We hypothesized that the relatively longtime $\mathrm{NaCl}$ effect drives the physiological distinctions among two types of tissue-cultured varieties of $U$. pumila during the ex vitro test and selections. 


\section{Materials and Methods}

\subsection{Plant material}

The plant material used in this study were 1-year-old seedlings obtained from tissue culture. Five genotypes from gene mutation of Ulmus pumila (\#1: original genotype No. '73001'; \#2: original genotype name ‘Mengxian'; \#3: original genotype No. ' 80025 ', \#5: original genotype No. '73006' and \#6 original genotype No. '65225') and one hybrid genotype (\#4: original genotype name $14 \times 2$ (4)) were selected from our former study[37]. Among them, three of them were salt-sensitive genotype ( $\# 1, \# 2$ and \#3) and three genotypes were salt-tolerant (\#4, \#5 and \#6).

\subsection{Experimental setup and salt treatments}

The study was carried out to examine the physiological changes and the different reactions between salt-tolerant and salt-sensitive elms when suffering the $\mathrm{NaCl}$ stress under the natural environment. Six genotypes were selected from the former study in vitro selection. The seedling materials used for this study initially obtained from the shoots tissue culture. For the first year, in vitro plants (about 200 plantlets per each) were transplants from the culture medium to seedbed in the greenhouse for acclimatization. Two months later, 120 seedlings with similar size (7 to $8 \mathrm{~cm}$ in height) of each genotype (720 seedlings in total) developed from the in vitro culture were selected and grown in $35 \mathrm{~cm}$ diameter pots filled with lemon soil (stylized with $0.27 \%$ of carbendazim) settled in the outdoor surrounding at the state nursery of Shandong Academic of Forestry, Jinan, China (117 $28^{\prime}$ E, $36^{\circ} 44^{\prime} \mathrm{N}$ ). Seedlings were grown under a natural environment with well-cultivated conditions such as irrigation and disinsection before starting $\mathrm{NaCl}$ treatment. In the second year, 30 seedlings with similar growth condition of each genotype were selected and moved into rainproof installations (open area covered with transparent film) at the forestry test station of Shandong Agriculture University, Tai'an, China $\left(116^{\circ} 20^{\prime} \mathrm{E}, 35^{\circ} 38^{\prime} \mathrm{N}\right)$.

The salt stress treatments were applied by immersing the pots with seedlings into different $\mathrm{NaCl}$ solutions. The treatment concentrations were $0 \%$ (control), $0.3 \%, 0.5 \%$, $0.7 \%, 0.9 \%(\mathrm{w} / \mathrm{v})$, which were equal to $51.3 \mathrm{mmol} \cdot \mathrm{L}^{-1}, 85.5 \mathrm{mmol} \cdot \mathrm{L}^{-1}, 119.7 \mathrm{mmol} \cdot \mathrm{L}^{-1}$, and $153.8 \mathrm{mmol} \cdot \mathrm{L}^{-1} \mathrm{NaCl}$ solution respectively. The $\mathrm{NaCl}$ represented low $(0.3 \%)$, medium $(0.5 \%$, and $0.7 \%)$, and high $(0.9 \%)$ salinity levels [27]. Based on the weather condition, pots with seedlings were soaked into different $\mathrm{NaCl}$ solution 6-10 hours per time and two to three times per week. To avoid the osmotic shock, for the higher salt treatment $(0.7 \%$ and $0.9 \%), \mathrm{NaCl}$ was added gradually over the period of one week. For the $0.7 \%$ and $0.9 \%$ treatments, the pots were immersed for three times consecutively into three $\mathrm{NaCl}$ solutions, i.e., $0.5 \%, 0.7 \%$, and $0.9 \%$, respectively. Every two weeks, the salt will be flushed from the soil to prevent soil build-up by adding fresh water from the top of the pots. Hoagland solutions $(25 \%)$ were used as the fertilizer and were added to the solutions every two weeks. In addition to the water condition, all the experiment was taking out under natural surroundings.

Before and after the treatments, individual seedlings' height and ground diameter were determined (103 days in total). During the second month of $\mathrm{NaCl}$ treatments (55 days, before the mortality started), gas exchange, leaf concentrations of chlorophyll, proline, sugars, and proteins were measured and the activities of superoxide dismutase (SOD), peroxidase (POD) were determined. At the end of the experiment, total biomass 
without leaves (plants start dormancy early under higher salt stress) and sodium concentrations were measured. The visible injury was recorded two weeks before harvesting. The condition of each seedling (referred to as health level or health score) was assigned and given a different score (ranging from 0 to 10) according to the overall plant performance level: with 10 indicating the plants had no visible injury with large size, 9 indicating no injury but smaller size; 8 indicating very minor leaf chlorosis; 7, 6, 5, 4, 3, 2, and 1 indicating up to $20 \%, 20-30 \%, 30-50 \%, 50-60 \%, 60-70 \%, 70-80 \%$, and $80-90 \%$, of leaves with chlorosis, respectively, while 0 indicated plant mortality [52].

\subsection{Measurements of the Free proline, chlorophyll, soluble protein, and sugar concentrations}

Free proline concentrations were analyzed according to the method of Bates, et al. [53] with some modifications. Extracts were prepared from $0.5 \mathrm{~g}$ of fresh mature leaves (in the middle position of the main stem) with $5 \mathrm{ml} 3 \%$ sulfosalicylic acid in a boiling water bath for $10 \mathrm{~min}$. After cooling, the extract was filtered and $2 \mathrm{ml}$ glacial acetic acid and $2 \mathrm{ml}$ ninhydrin were added to $2 \mathrm{ml}$ of the filtered extract. After $30 \mathrm{~min}$ of incubation in a water bath at $100^{\circ} \mathrm{C}$, the mixture was cooled and $4 \mathrm{ml}$ methylbenzene was added. The mixture was shaken for $30 \mathrm{~s}$ and centrifuged at $3000 \times \mathrm{g}$ for $5 \mathrm{~min}$ prior to the spectrophotometric measurements. The absorbance of extracts was recorded at $520 \mathrm{~nm}$ and the concentrations of proline were determined from the standard curve prepared for pure proline (SigmaAldrich) according to Bates et al. [53].

Leaf chlorophyll was extracted from $0.2 \mathrm{~g}$ fresh mature leaves (both healthy and injured) with $4 \mathrm{ml}$ of $80 \%$ acetone, $95 \%$ ethanol, and water $\left(3: 6: 1\right.$, by volume) at $60^{\circ} \mathrm{C}$ for two hours. After cooling to the ambient temperature and centrifuging at $2500 \times \mathrm{g}$ for $5 \mathrm{~min}$, the absorbance of extracts was read at 645 and $663 \mathrm{~nm}$ to determine the chlorophyll a and b concentrations [54].

Soluble proteins were extracted from $0.2 \mathrm{~g}$ fresh mature leaves (in the middle position of the main stem) with $2 \mathrm{ml}$ extraction buffer (10 mM Tris-HCl, 10\% glycerol, 5\% PVP, $1.0 \%$ Triton $\mathrm{X} 100$ ) at $\mathrm{pH} 6.8$. The protein extracts were centrifuged at $12000 \times \mathrm{g}$ for $20 \mathrm{~min}$ at $4{ }^{\circ} \mathrm{C}$ before use, then the sample was analyzed with the spectrophotometer using the protein dye-binding method [55].

The tissue sugar concentrations were analyzed with the anthrone reagent method described by Sadasivam and Manickam [56]. Briefly, $0.5 \mathrm{~g}$ samples of mature leaves (in the middle position of the main stem) were extracted in $25 \mathrm{ml}$ distilled water in a water bath $\left(100^{\circ} \mathrm{C}\right)$ for $30 \mathrm{~min}$ twice. Anthrone $(0.5 \mathrm{ml})$ in $5 \mathrm{ml} \mathrm{H}_{2} \mathrm{SO}_{4}$ was added to $50 \mathrm{ul}$ of filtered extracts (with $1.95 \mathrm{ml}$ distilled water). The absorbance was measured at $630 \mathrm{~nm}$ and the total soluble sugar concentration was calculated using the standard curve obtained for the glucose.

\subsection{Antioxidant enzyme, superoxide dismutase (SOD), peroxidase (POD), and catalase (CAT) activities}

We prepared the enzyme assays as following, the $0.5 \mathrm{~g}$ fresh mature leaves were ground to a fine powder by using the liquid nitrogen; and then we produced the extracts with 3 $\mathrm{ml}$ of $50 \mathrm{mmol} \mathrm{L}^{-1} \mathrm{Na}_{2} \mathrm{HPO}_{4}-\mathrm{NaH}_{2} \mathrm{PO}_{4}$ buffer (pH 7.0), containing $1.0 \mathrm{mmol} \mathrm{L}^{-1}$ EDTA, 0.05 $\%(\mathrm{v} / \mathrm{v})$ Triton $\mathrm{X}-100,2 \%(\mathrm{w} / \mathrm{v})$ PVP. The extracts were centrifuged at $4^{\circ} \mathrm{C}$ for $30 \mathrm{~min}$ at $20000 \times g$ and the supernatants were used to assay the antioxidant enzyme activities. 
The SOD activity was assayed by measuring the inhibition of photochemical reduction of nitro blue tetrazolium (NBT) [57,58]. One unit superoxide dismutase was defined as the amount of enzyme required to lead to a half percentage of inhibition of the rate of NBT reduction measured at $560 \mathrm{~nm}$.

For the POD activity, changes in absorbance at $470 \mathrm{~nm}$ were measured every minute in the supernatants (obtained as described above) according to Civello, et al. [59]. A unit of peroxidase activity was expressed as the change in absorbance.

We measured the CAT activity measurement based on the homogenates that were centrifuged at $4^{\circ} \mathrm{C}$ for $30 \mathrm{~min}$ at $20000 \times \mathrm{g}$. The supernatants were estimated by measuring the decrease in absorbance due to the disappearance of $\mathrm{H}_{2} \mathrm{O}_{2}$ at $240 \mathrm{~nm}$ due to degradation of hydrogen peroxide using the method of Aebi [60].

\subsection{Leaf gas exchange measurements}

Net photosynthetic rate $(\mathrm{Pn})\left(\mu \mathrm{mol} \cdot \mathrm{m}^{-2} \cdot \mathrm{s}^{-1}\right)$, transpiration rate $(\mathrm{Tr})\left(\mathrm{mmol} \cdot \mathrm{m}^{-2} \cdot \mathrm{s}^{-1}\right)$, were measured on six plants per genotype per treatment combination using a CIRAS-2 portable photosynthesis system (PP Systems, Amesbury, MA, USA). Measurements were carried out at constant ambient conditions (the photosynthetic photon flux density was maintained at $1000 \mu \mathrm{mol} \cdot \mathrm{m}^{-2} \cdot \mathrm{s}^{-1}$, the leaf temperature kept at $28^{\circ} \mathrm{C}$ and the $\mathrm{CO}_{2}$ concentration maintain at $360 \mu \mathrm{mol} \cdot \mathrm{mol}^{-1}$ ). All measurements were carried out between 09:00 and 11:00 am during continuous sunny days and the upper fully development leaves were used for the gas exchange measurements. Water use efficiency (WUE) was calculated as the quotient of the net photosynthesis and the transpiration rate, i.e., WUE $=\operatorname{Pn} / \operatorname{Tr}$ [61].

\subsection{Growth experiment set up and measurements}

After 103 days, plant height and ground diameter were measured again to determine height and ground diameter growth rates; the dry weight of shoot and root were used as total biomass (for salt-sensitive genotypes, all growth data were collected after the death happened). Height relative growth rate (HR), ground diameter relative growth rate (DR) and the biomass were used as growth indicators. The height relative growth rate (HR) was determined as $\frac{\text { (Plant final height - Plant initial height) }}{\text { Plant initial height }} \times 100 \%$. The ground diameter relative growth rate (DR) was calculated as $\frac{(\text { Plant final ground diameter }- \text { Plant initial ground diameter) }}{\text { Plant initial ground diameter }} \times 100 \%$.

\subsection{Data analysis}

Growth parameters were measured in six genotypes $(n=6)$ in each per treatment per genotype. The one-way ANOVA was carried out by the Data Processing System software (SPSS version 19, Chicago, IL, USA) and the means denoted by different letters were significantly different at $p$-Value $<0.05$ based on Duncan's multiple range tests. Principal Component Analysis (PCA) was carried out with the $\operatorname{prcomp}()$ function in $\mathrm{R}$ and the plot was made with the foiz_pca_biplot() in the FactoMineR and factoextra packages in R ( $\mathrm{R}$ Core Team, 2013. http://www.R-project.org/).

There were two samples per treatment with three replications $(n=6)$ measured for superoxide dismutase (SOD), catalase (CAT), peroxidase (POD), free proline, total chlorophyll, malondialdehyde (MDA), soluble protein, sugar concentrations, and gas-exchange. The results were analyzed by a hierarchical analysis of variance (Nested ANOVA) 
using R v3.1.2 core functions [62] based on the degree of salt tolerance (salt-tolerant group and salt sensitive group). The significance level $(\alpha)$ was 0.05 .

\section{Results}

\subsection{Plant mortality}

Salt-sensitive genotypes started dying at $0.7 \% \mathrm{NaCl}$ after two months later. After 103 days of different concentration of $\mathrm{NaCl}$, all plants of sensitive genotypes (\#1, \#2 and \#3) were dead under the $0.9 \% \mathrm{NaCl}$. For the salt-sensitive genotype $\# 1, \# 2$ and $\# 3$, the mortality was $100 \%, 0 \%$ and $100 \%$ respectively under the $0.7 \% \mathrm{NaCl}$. On the contrary, the salt-tolerant genotypes (\#4, \#5 and \#6) had zero mortality in all $\mathrm{NaCl}$ after 103 days.

\subsection{Plant morphology}

$\mathrm{NaCl}$ stress severely affected the morphology and induced plant injuries in both salt-sensitive genotypes ( $\# 1, \# 2$, and $\# 3$ ) and salt-tolerant genotypes (\#4, \#5, and \#6) in the middle and high $\mathrm{NaCl}$ after a period of three months' treatment. In low $\mathrm{NaCl}$, the salt-tolerant genotypes were less affected (Table 1). When $\mathrm{NaCl}$ increased, the health level of salt-tolerant genotypes declined. In the $0.9 \% \mathrm{NaCl}$, the average level of salt-tolerant genotypes reached $\sim 3$, that $60 \%$ to $70 \%$ of leaves showed visible injuries.

The growth and visible injuries among the salt-sensitive genotypes were driven by low salt concentration. For Genotype \#1, the score was 2 which meant that $70 \%$ to $80 \%$ of total leaves showed chlorosis or dead at $0.3 \% \mathrm{NaCl}$ (Table 1). In genotype \#2, the health score showed that $60 \%-70 \%$ of the plants' leaves were chlorosis or damaged at $0.3 \% \mathrm{NaCl}$ (Table 1). The score in genotype \#3 indicates that $50 \%$ to $60 \%$ of the visible injury was shown at $0.3 \% \mathrm{NaCl}$ (Table 1). The score showed a declining tendency with increasing salt concentrations in $\mathrm{NaCl}$ (Table 1).

Table 1. Seedlings performance indices of six $U$. pumila genotypes subjected to different $\mathrm{NaCl}$ concentration treatments.

\begin{tabular}{|c|c|c|c|c|c|c|}
\hline \multirow{2}{*}{$\begin{array}{l}\mathrm{NaCl} \\
\text { concentration }\end{array}$} & \multirow[b]{2}{*}{$\# 1$} & \multicolumn{4}{|c|}{ Score of plants healthy } & \multirow[b]{2}{*}{$\# 6$} \\
\hline & & $\# 2$ & $\# 3$ & $\# 4$ & $\# 5$ & \\
\hline $0.0 \%$ & $10.0 \pm 0.0$ & $10.0 \pm 0.0$ & $\begin{array}{l}10.0 \\
\pm 0.0\end{array}$ & $10.0 \pm 0.0$ & $10.0 \pm 0.0$ & $10.0 \pm 0.0$ \\
\hline $0.3 \%$ & $2.0 \pm 0.0$ & $3.0 \pm 0.0$ & $5.0 \pm 0.0$ & $6.2 \pm 0.3$ & $5.0 \pm 0.0$ & $5.0 \pm 0.0$ \\
\hline $0.5 \%$ & $1.3 \pm 0.2$ & $2.2 \pm 0.2$ & $3.5 \pm 0.5$ & $5.3 \pm 0.2$ & $4.7 \pm 0.2$ & $4.0 \pm 0.0$ \\
\hline $0.7 \%$ & $0.0 \pm 0.0$ & $1.3 \pm 0.2$ & $0.0 \pm 0.0$ & $4.3 \pm 0.2$ & $4.0 \pm 0.0$ & $4.0 \pm 0.0$ \\
\hline $0.9 \%$ & $0.0 \pm 0.0$ & $0.0 \pm 0.0$ & $0.0 \pm 0.0$ & $3.3 \pm 0.2$ & $2.5 \pm 0.2$ & $3.3 \pm 0.2$ \\
\hline
\end{tabular}

Notes, means $(n=6) \pm$ standard error. 


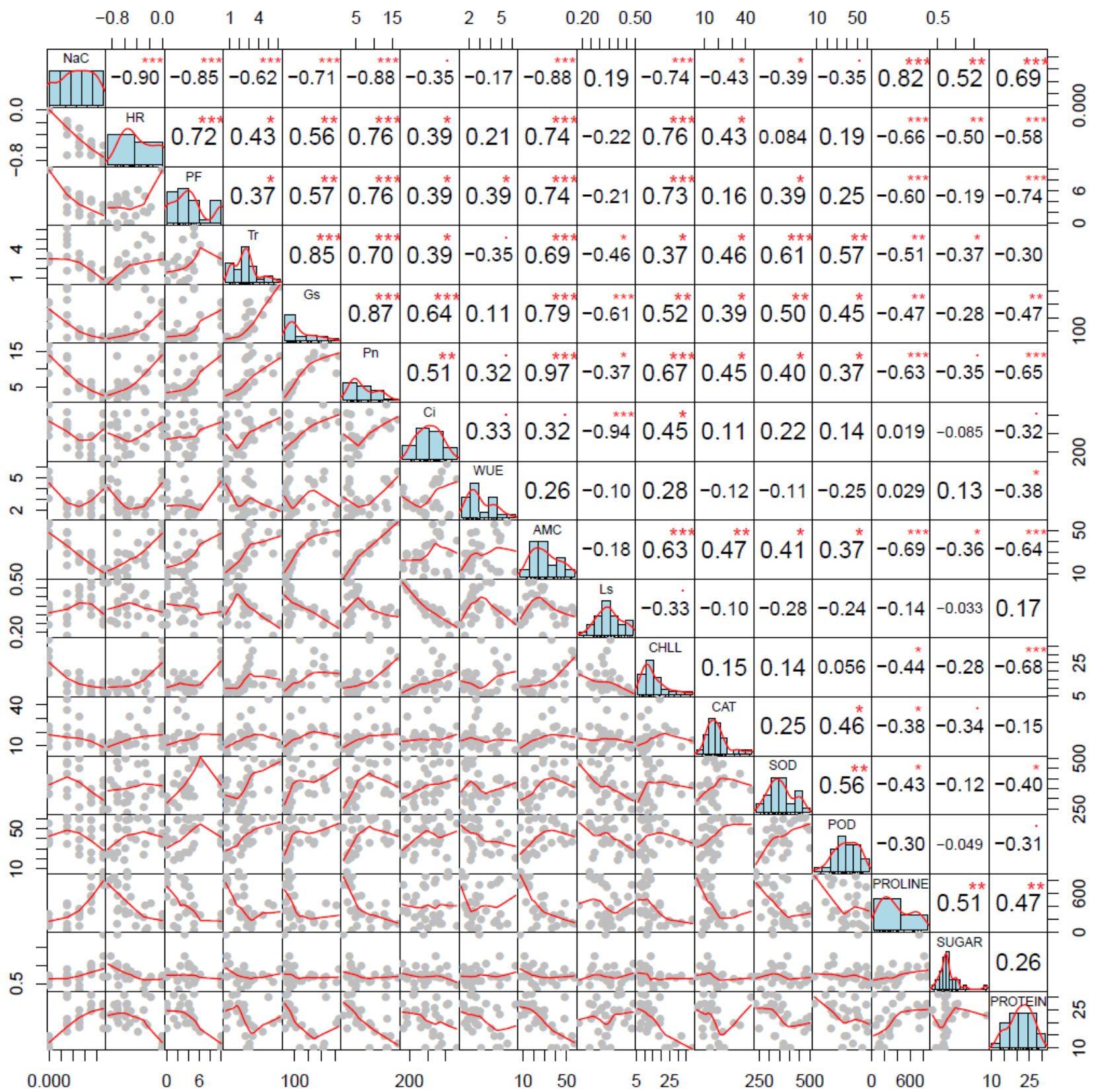

Figure 1. Correlation and histogram of physiological variables and $\mathrm{NaCl}$ treatment $(\mathrm{NaC})$ including height growth rate ( $\mathrm{HR}, \%)$, performance indices ( $\mathrm{PF})$, transpiration rate (Tr), Stomatal conductance (Gs), average net photosynthesis rate (Pn), water use efficiency (WUE), internal carbon concentration (Ci), apparent mesophyll conductance (AMC), stomatal limitation percentage (Ls), chlorophyll (CHLL), CAT, SOD, POD, Proline, sugar, and protein. Pearson's correlation coefficients are in the right upper diagonal, the scatter plots are in the lower-left diagonal for the pairs of physiological variables, while the diagonal are the histograms of each variable. The p-values are denoted as following ${ }^{* * *}<0.0001$, $* *<0.001, *<0.05$. The first column of scatter plots and first row of correlation showed the relationship between $\mathrm{NaC}$ and all tested traits. 


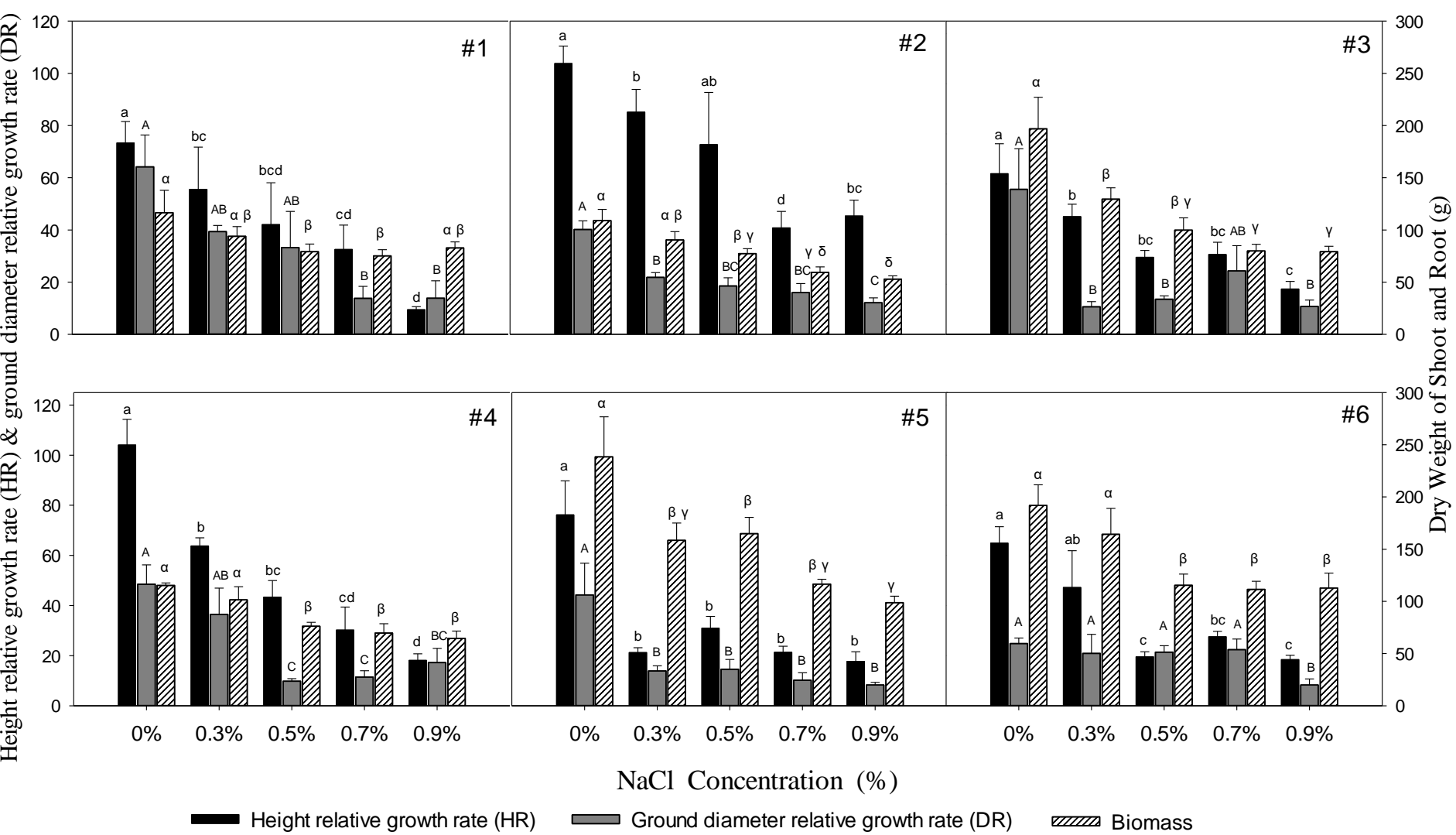

Figure 2. Height relative growth rate (HR), ground diameter relative growth rate (DR), and dry weight of shoot and root (biomass) in 6 genotypes of $U$. pumila subjected to different $\mathrm{NaCl}$ concentration treatments. Means $(\mathrm{n}=6) \pm \mathrm{SE}$ are shown. Means followed by different letters are significantly different at $\mathrm{P}<0.05$ according to Duncan's multiple range test.

\subsection{Effects of $\mathrm{NaCl}$ on growth parameters}

Height relative growth rate (HR), ground diameter relative growth rate (DR) and dry weight of shoot and root (biomass) decreased in the six studied genotypes with the increase in $\mathrm{NaCl}$ concentrations (Figure 2). Salt-sensitive genotypes had less affected on $\mathrm{HR}$ but more affected on DR and biomass compared with the salt-tolerant genotypes by the same concentrations of $\mathrm{NaCl}$. Under low salt stress $(0.3 \% \mathrm{NaCl})$, the $\mathrm{HR}$, DR, and biomass in salt-sensitive genotypes were $23 \%, 55 \%$, and $24 \%$ lower on average than the untreated control, respectively (Figure 1A, 1B, 1C). In salt-tolerant genotypes, the HR, DR, and biomass were $46 \%, 36 \%$ and $20 \%$ lower on average than the untreated control under low salt treatment, respectively (Figure 1D, 1E, and 1F). In the high salt treatment $(0.9 \% \mathrm{NaCl})$, the HR, DR and biomass in salt-sensitive genotypes were $72 \%, 76 \%$, and $47 \%$ lower on average than control, and $77 \%, 71 \%$, and $48 \%$ lower on average than the control in salt-tolerant genotypes, respectively (Figure 2). 
Table 2. Nested ANOVA analysis of osmoregulation content, reactive oxygen species, gas exchange and sodium concentration in U. pumila between salt-tolerance and salt-sensitive group under $\mathrm{NaCl}$ treatment

\begin{tabular}{cllll}
\hline $\begin{array}{c}\text { Physiological } \\
\text { indicator }\end{array}$ & \multicolumn{2}{c}{ Group } & \multicolumn{2}{c}{ Group: Genotypes } \\
\hline Sugar & 1229.810 & $* * *$ & 13.479 & $* * *$ \\
Free proline & 329.720 & $* * *$ & 698.79 & $* * *$ \\
Soluble protein & 87.387 & $* * *$ & 97.353 & $* * *$ \\
SOD & 1648.780 & $* * *$ & 60.004 & $* * *$ \\
POD & 712.560 & $* * *$ & 785.05 & $* * *$ \\
CAT & 48.159 & $* * *$ & 33.624 & $* * *$ \\
Chlorophyll & 40.057 & $* * *$ & 2425.341 & $* * *$ \\
Pn & 9.736 & $* *$ & 32.2182 & $* * *$ \\
Tr & 0.252 & - & 11.8733 & $* * *$ \\
WUE & 0.050 & - & 2.2644 & - \\
\hline
\end{tabular}

Notes, ${ }^{* * *}$ mean significant at 0.001 level; ${ }^{* *}$ mean significant at 0.01 level; - mean not significant.
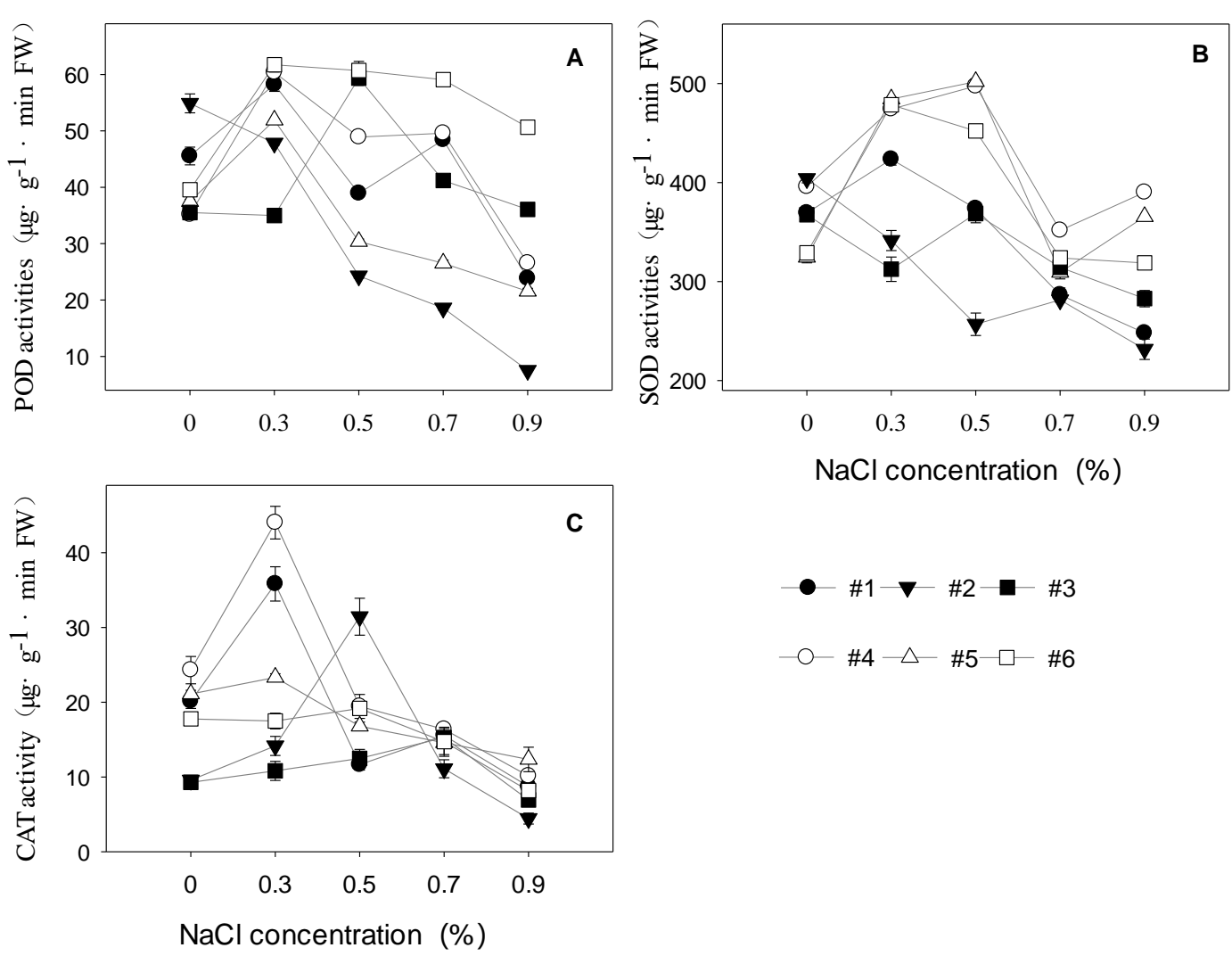

Figure 3. Changes in antioxidant enzyme activities subjected to $\mathrm{NaCl}$ treatments. Means $(\mathrm{n}=3) \pm \mathrm{SE}$ are shown $(\mathrm{A}, \mathrm{POD}$ activities; B, SOD activities; C CAT activities). 

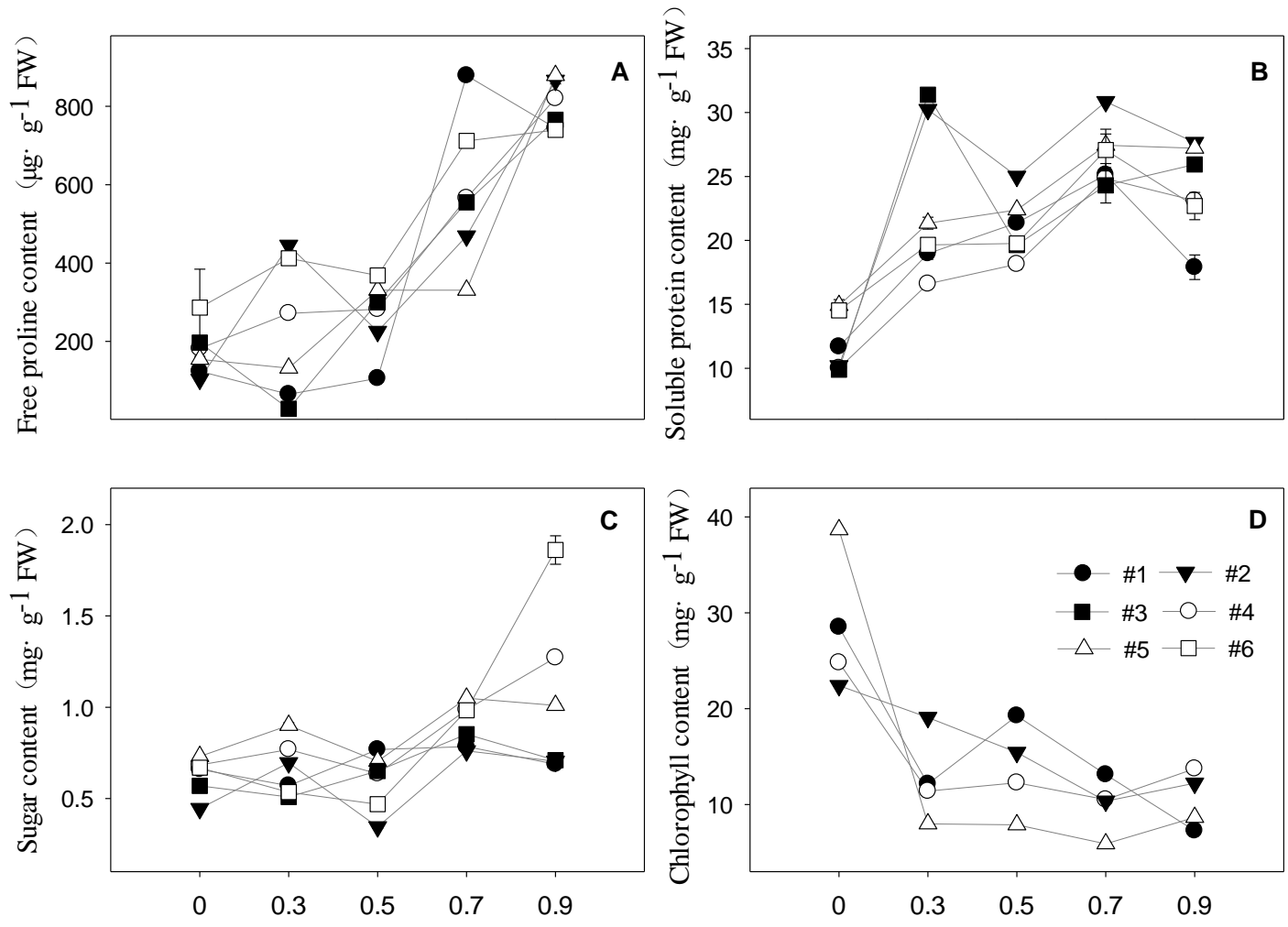

$\mathrm{NaCl}$ Concentration (\%)

Figure 4. Changes in chlorophyll, soluble protein, sugar, and free proline subjected to treatments. Means $(n=3) \pm S E$ are shown (a free proline content; b soluble protein content; c sugar content; $d$ chlorophyll content in the $\mathrm{NaCl}$ treatments).

\subsection{Nested ANOVA}

We using the nested ANOVA to compare the difference of physiology parameters (SOD, POD, CAT, free proline, soluble protein, sugar, chlorophyll, and gas exchange indexes) between two groups (salt-sensitive genotypes and salt-tolerant genotypes). The result showed that the differences of SOD, POD, CAT, free proline, soluble protein, sugar, chlorophyll, net photosynthesis (Pn), between the salt-sensitive group and salt-tolerant group are significant (Table 2). While the result of transpiration rate (Tr), and water use efficiency (WUE) between the two groups are not significant (Table 2).

\subsection{Antioxidant enzyme activities}

$\mathrm{NaCl}$ drove the tissue peroxidase (POD) variation in different genotypes (Figure 3A). In genotype \#1, the POD activity increased in $0.3 \%$ and $0.7 \% \mathrm{NaCl}$, decreased at $0.5 \%$ and $0.9 \% \mathrm{NaCl}$ compared with the control. The POD activity decreased with the increase of $\mathrm{NaCl}$ concentrations in genotype \#2. In genotype \#3, the POD activity decline at $0.3 \%$ 
$\mathrm{NaCl}$, increased at middle $(0.5 \%$ and $0.7 \%)$ and high $(0.9 \%) \mathrm{NaCl}$. For salt-tolerant genotypes, a sharp increase of POD activity was measured at $0.3 \% \mathrm{NaCl}$. In genotype \#4, the POD activity increase in middle $\mathrm{NaCl}$ and a decline in the level below the control in high $\mathrm{NaCl}$. The POD activity in genotype \#5 decreased under rising $\mathrm{NaCl}$ concentrations $(\mathrm{NaCl}$ $>0.5 \%$ ). Salt treatment elevated the activities of the POD in genotype $\# 6$, at $0.9 \% \mathrm{NaCl}$, the POD activity was still $28 \%$ greater than in control.

Superoxide dismutase (SOD) activity kept at relatively higher concentrations in salttolerant genotype than salt-sensitive genotype under all $\mathrm{NaCl}$ (Figure 2B). In salt-tolerant genotypes, the activity of SOD enzyme increased in $0.3 \%$ and $0.5 \% \mathrm{NaCl}$. The increased SOD activity in salt-tolerant at $0.5 \% \mathrm{NaCl}$ was $39 \%$ greater on average compared with untreated control. A slight decline in SOD activity was observed in salt-tolerant genotypes at $0.7 \%$ and $0.9 \% \mathrm{NaCl}$ except genotype $\# 5$ (increased in $0.9 \% \mathrm{NaCl}$ ). On the contrary, $\mathrm{NaCl}$ stress decreased the SOD activity in most of the salt-sensitive genotypes (Figure 2B). In genotype \#2, SOD activity decreased with the increasing $\mathrm{NaCl}$ concentrations. A similar reduction in SOD activity was shown in genotype \#3 except a $0.34 \%$ increase than the control in $0.5 \% \mathrm{NaCl}$. The SOD activity in genotype \#1 increased slightly in $0.3 \%$ and $0.5 \%$ $\mathrm{NaCl}$ and a sharp decline below the control at the $0.7 \%$ and $0.9 \% \mathrm{NaCl}$.

The catalase (CAT) activity in leaves increased in lower salt ( $\mathrm{NaCl} 0.3 \%$ to $0.7 \%)$ treatments, decreased at higher salt $(\mathrm{NaCl} 0.7 \%$ to $0.9 \%)$ treatments (Figure $2 \mathrm{C}$ ). In salttolerant genotypes, the activity of CAT activity reached the top in $0.3 \%$ or $0.5 \% \mathrm{NaCl}$ which was $33.25 \%$ greater on average compared with untreated control. The CAT activity declined at $0.5 \%$ or $0.7 \% \mathrm{NaCl}$ and dropped to the bottom in $0.9 \% \mathrm{NaCl}$. In $0.9 \% \mathrm{NaCl}$, the average of CAT activity in salt-tolerant genotypes was $51.22 \%$ lower compared with untreated control. In salt-sensitive genotypes (\#1, \#2 and \#3), the activity of CAT enzyme reached the peak level in $0.3 \%, 0.5 \%$ and $0.7 \%$ respectively. The average of CAT activity in the peak was $88.02 \%$ greater compared with untreated control. The activity of CAT enzyme in salt-sensitive genotypes dropped to the bottom at $0.9 \% \mathrm{NaCl}$ which was $50.18 \%$ lower compared with untreated control.

\subsection{Proline tissue concentrations}

Free proline (Pro) tissue concentration increased with the increasing salt treatment concentration in most of the genotypes, except for genotype \#3 and \#5 which decreased at $0.3 \% \mathrm{NaCl}$, and genotype $\# 1$ with a decrease at $0.3 \%$ and $0.5 \%$ of $\mathrm{NaCl}$ (Figure $3 \mathrm{~A}$ ). In $0.9 \%$ $\mathrm{NaCl}$, all genotypes' tissue Pro reached the highest except genotype \#1 (with the maximum proline levels in $0.7 \% \mathrm{NaCl}$ ). The concentration of proline in salt-sensitive genotypes averaged at $792 \mu \mathrm{g} \cdot \mathrm{g}^{-1}$ which was 5 times higher than control at $0.9 \% \mathrm{NaCl}$. In salt-tolerant genotypes, the average Pro concentration reached $813 \mu \mathrm{g} \cdot \mathrm{g}^{-1}$ in $0.9 \% \mathrm{NaCl}$ which was 3.3 times higher than the untreated control.

\subsection{Soluble protein concentrations}

Effects of $\mathrm{NaCl}$ increased the concentration of tissue soluble protein (SP) in all genotypes (Figure 3B). In salt-tolerant genotypes, the maximum SP tissue concertation was measured in $0.7 \% \mathrm{NaCl}$, the concentrations were $106 \%$ greater on average than the control. Similar 
patterns were found for salt-sensitive genotypes with the maximum proline levels induced by $0.7 \% \mathrm{NaCl}$, except for genotypes \#3 which showed the highest SP levels in $0.3 \%$ (Figure 3B).

\subsection{Sugar tissue concentrations}

The tissue sugar levels in salt-tolerant genotype were higher than salt-sensitive genotype in higher $\mathrm{NaCl}(0.7 \%$ and $0.9 \% \mathrm{NaCl})$ (Figure 3C). Generally, the sugar concentration in salt-tolerant genotypes increased with the increasing $\mathrm{NaCl}$ except $0.5 \% \mathrm{NaCl}$ concentration (which had a decrease of sugar content). The concentration of sugar in salt-sensitive genotypes decreased at $0.3 \%$ or $0.5 \% \mathrm{NaCl}$, the maximum values were measured in $0.7 \%$ $\mathrm{NaCl}$. In $0.7 \% \mathrm{NaCl}$, the sugar concentration in salt-sensitive genotypes was $0.78 \mathrm{mg} \cdot \mathrm{g}^{-1}$ $(\# 1), 0.76 \mathrm{mg} \cdot \mathrm{g}^{-1}(\# 2)$ and $0.85 \mathrm{mg} \cdot \mathrm{g}^{-1}(\# 3)$, which was $46 \%$ higher on average than the control. In $0.9 \% \mathrm{NaCl}$, the average increases of sugar content in salt-sensitive genotype was $29 \%$ higher than the untreated control. While, in salt-tolerant genotype, the sugar concentration was $0.99 \mathrm{mg} \cdot \mathrm{g}^{-1}(\# 4), 1.05 \mathrm{mg} \cdot \mathrm{g}^{-1}$ (\#5) and $0.98 \mathrm{mg} \cdot \mathrm{g}^{-1}(\# 6)$ in $0.7 \% \mathrm{NaCl}$, and 1.27 $\mathrm{mg} \cdot \mathrm{g}^{-1}(\# 4), 1.01 \mathrm{mg} \cdot \mathrm{g}^{-1}(\# 5)$ and $1.86 \mathrm{mg} \cdot \mathrm{g}^{-1}(\# 6)$ in $0.9 \% \mathrm{NaCl}$ which was $45 \%$ and $101 \%$ higher on average than the control, respectively.

\subsection{Chlorophyll}

Generally, total chlorophyll concentrations decreased with the increasing salt treatment concentrations in both salt-sensitive and salt-tolerant genotypes (Figure 3D). In 0.9\% $\mathrm{NaCl}$, the reduction of chlorophyll concentration averaged $65.8 \%$ in salt-sensitive genotypes, compared with about $50.5 \%$ for salt-tolerant genotypes at $0.9 \% \mathrm{NaCl}$.

\subsection{Leaf gas exchange}

Net photosynthesis rate ( $\mathrm{Pn})$ decreased with increasing of the $\mathrm{NaCl}$ treatments in both the salt-sensitive and the salt-tolerant genotypes (Table 3). The transpiration rate (Tr) increased at $0.3 \% \mathrm{NaCl}$, decrease at middle and high $\mathrm{NaCl}$ treatment of except genotype \#3 (with a transpiration rate decline from $0.3 \%$ to $0.9 \% \mathrm{NaCl}$ ) (Table 3). The water use efficiency (WUE) showed a decrease in genotype \#3, \#4, and \#5. In $0.9 \% \mathrm{NaCl}$ concentration, an increase of (WUE) was measured in genotype \#1, \#2, and \#6. The WUE in genotypes $\# 1$, \#2 and \#6 were lower in $\mathrm{NaCl}$ than the control. While for genotypes \#3, \#4, and \#5 the WUE decreased in $0.3 \%$ to $0.7 \% \mathrm{NaCl}$ increased in $0.9 \% \mathrm{NaCl}$. 


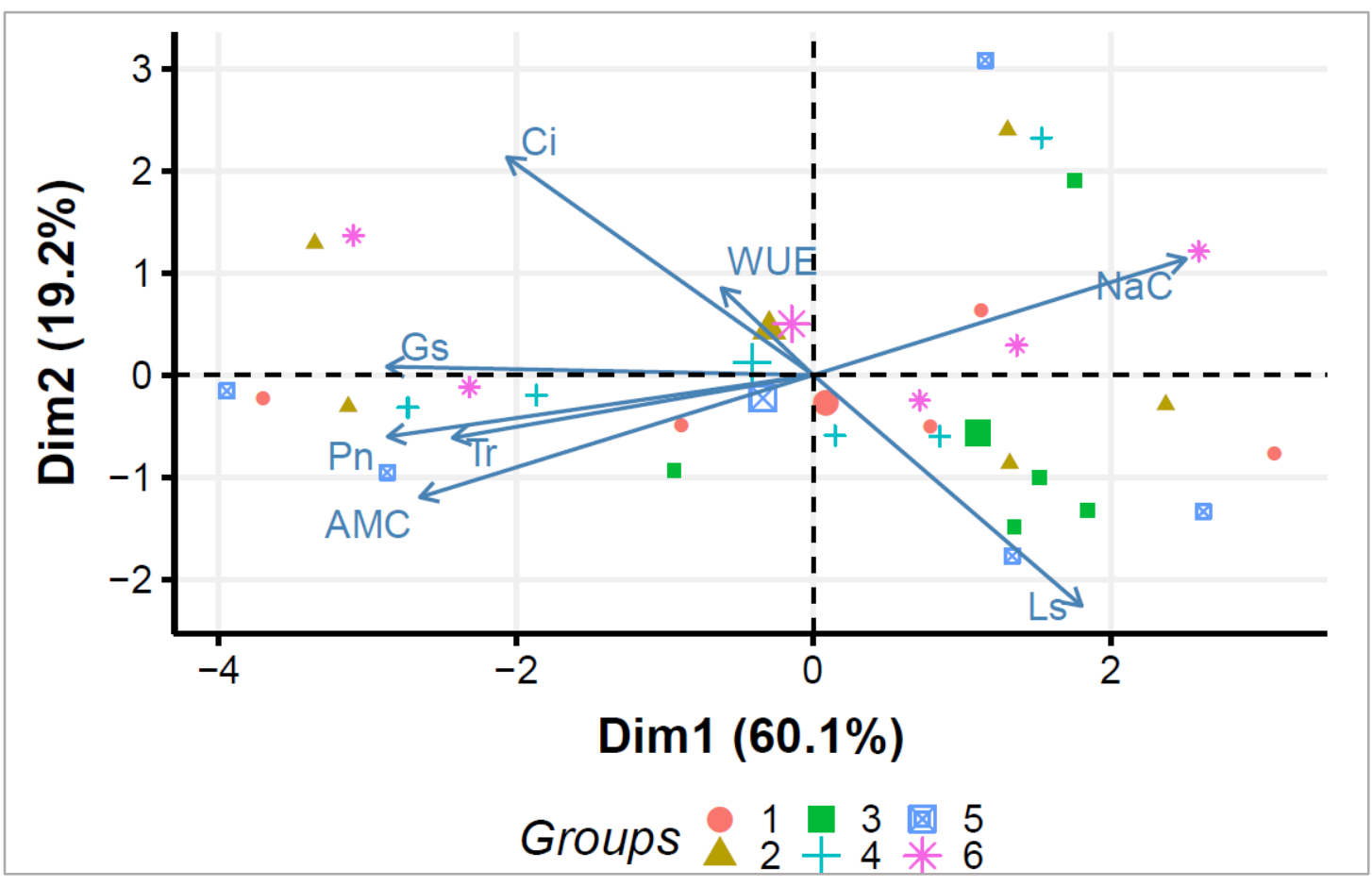

Figure 5. Principal component analyses (PCA) biplot of clonal average net photosynthesis rate (Pn), transpiration rate (Tr), water use efficiency (WUE), Ci (internal carbon concentration), AMC (apparent mesophyll conductance), Ls (stomatal limitation percentage), change in different $\mathrm{NaCl}$ concentration treatments (NaC) of 6 genotypes of $U$. pumila (color groups). $\mathrm{NaC}, \mathrm{NaCl}$ treatment concentration. The principal components 1 and 2 (i.e., Dim 1 and Dim 2) explained $60.1 \%$ and $19.2 \%$ of total variance. WUE, Ls and Ci were not correlated with NaC gradient.

\subsection{Phenotypic correlation and the correlations between $\mathrm{NaCl}$ treatment and traits}

The phenotypic Pearson's correlation coefficients (Figure 1) showed that plant height growth, and performance indices were positively correlated with photosynthesis rate (Pn), AMC apparent mesophyll conductance), and chlorophyll (CHLL) with $\mathrm{r}$ ranging from 0.7 to $0.8^{* * *}$, but were negatively related to the free proline, sugar, and protein accumulation $\left(\mathrm{r}=-0.5--0.7^{* * *}\right)$. The proline was positively related to $\mathrm{NaCl}\left(0.82^{* * *}\right)$, which was stronger than the relationship between $\mathrm{NaCl}$ and sugar or protein accumulation $(\mathrm{r}=$ 0.5-0.7 $\left.{ }^{* * *}\right)$. However, growth performance, photosynthesis traits were negatively correlated with $\mathrm{NaCl}$. Height, performance indices, stomatal conductance (Gs), AMC, and chlorophyll were negatively correlated with $\mathrm{NaCl}\left(\mathrm{r}=-0.7\right.$ to $\left.-0.9^{* * *}\right)$. SOD, POD, and CAT were negatively associated with $\mathrm{NaCl}\left(\mathrm{r}=-0.4^{*}\right)$. WUE was negatively linked with $\mathrm{NaCl}$ but was not significant. A similar trend was shown in the PCA biplot in Figure 5 for multiple physiological traits and $\mathrm{NaCl}$ concentrations. 


\section{Discussion}

The effect of salt stress is manifested by changes in growth (promote or inhibition), morphology, and physiology, e.g., leaf abscission and death, increasing activates of superoxide dismutase enzyme, and declining photosynthetic capacity [8]. The survival rate is a reliable criterion to evaluate salt tolerance. Sodium chloride $(\mathrm{NaCl})$ is the major cause of the inhibition or death to most of the glycophytes; as low as $20 \mathrm{mmol} \cdot \mathrm{L}-1(0.117 \%) \mathrm{NaCl}$ could inhibit the growth of plants [63]. Here we found that the growth of $U$. pumila seedlings decreased with the jump of $\mathrm{NaCl}$ concentrations. When $\mathrm{NaCl} \geq 0.7 \%$, the severity of the reduction happened in both salt-tolerant and salt-sensitive plants (Figure 2). Regarding the salt-sensitive group, over $60 \%$ of the seedlings showed visible injury or leaf chlorosis show in $0.5 \% \mathrm{NaCl}$ (Table 1) with the mortality rate reaching $100 \%$ at $\mathrm{NaCl}>0.7 \%$. On the contrary, all the seedlings of salt-tolerant genotypes kept alive after the one-year period salt treatments, the visible injury and leaf chlorosis was between $60 \%$ and $70 \%$ under $0.9 \% \mathrm{NaCl}$ (Table 1). Our findings confirmed with the feasibility of previous studies in vitro selection of salt-tolerant $U$. pumila [37].

Salt stress could lead to oxidative stress in plants by raising reactive oxygen species (ROS) rapidly [64]. ROS, such as superoxide $\left(\mathrm{O}_{2}-\right)$, hydrogen peroxide $\left(\mathrm{H}_{2} \mathrm{O}_{2}\right)$, and hydroxyl radicals $(\mathrm{OH}-)$, can cause cellular damages in plants [24]. To overcome the oxidative stress induced by salinity, the ROS scavenging system, such as SOD, CAT, and POD is activated and elevated to defend against oxidative stress [65]. The decrease of the ROS scavenging system often occurs when the salt concentration exceeds the threshold value [51]. Among these ROS scavenging systems, SOD is a key enzyme to maintain a normal physiological process and cope with the oxidative stress by converting $\mathrm{O}_{2}{ }^{-}$to $\mathrm{O}_{2}$ and $\mathrm{H}_{2} \mathrm{O}_{2}$ rapidly [66]. In our study, salinity caused a sharp increase in the SOD activity in the seedlings of salt-tolerant genotypes (\#4, \#5, and \#6) under lower $\mathrm{NaCl}(0.3 \%, 0.5 \%)$. Under higher $\mathrm{NaCl}$, the SOD activity of salt-tolerant genotypes slightly dropped at the $0.7 \%$ salt concentration and rebounded at the $0.9 \%$ salt treatment (Figure 3B). On the contrary, SOD activity showed a declining trend in all salt-sensitive genotypes (\#1, \#2 and \#3) (Figure 2B). Given the function of SOD, the salt-tolerant $U$. pumila genotypes are likely to possess a stronger $\mathrm{O}_{2}$ - scavenging ability than the salt-sensitive genotypes. Our results are comparable to previous studies of crop genotypes, such as wheat (Triticum aestivum) [67], perennial ryegrass (Lolium perenne) [47] and maize (Zea mays) [68]. The product of SOD activity is hydrogen peroxide $\left(\mathrm{H}_{2} \mathrm{O}_{2}\right)$, which can cause oxidative damage when the concentrations higher in the cell [69].

Various enzymes regulate $\mathrm{H}_{2} \mathrm{O}_{2}$ in plants' cell such as CAT and POD [70]. We found that the activity of CAT in salt-tolerant and salt-sensitive genotypes both increased in the lower $\mathrm{NaCl}$ and decreased at higher $\mathrm{NaCl}$. The POD activity demonstrated a similar trend in both salt-tolerant and salt-sensitive genotypes under different $\mathrm{NaCl}$ concentration treatment (Figure 3A). The similar results agreed with the previous study of the in vitro selection of U. pumila [37] and soybean (Glycin max) [71].

By comparing the salt-tolerant and the salt-sensitive genotypes, we demonstrated no different tendency in the activity of CAT and POD enzyme (Figure 3B,C). In general, the over-reduction of the electron chain along with the lack of regeneration of the final electron acceptor in PSI (NADP+) favor electron transfer from ferredoxin to oxygen to form $\mathrm{O}_{2}-$ (Mehler Reaction) in chloroplasts, which undergoes dismutation to $\mathrm{H}_{2} \mathrm{O}_{2}$ and $\mathrm{O}_{2}$ that is catalyzed by the superoxide dismutase (SOD) [72]. The opposite reaction of SOD activity between salt-tolerant and salt-sensitive genotypes could indicate that the SOD activities have played a crucial protective role against the oxidative stress in salt-tolerant genotypes $U$. pumila caused by salt stress. 
Osmotic stress and ionic stress are the two major stresses due to high salinity [26]. Under salt stress, the accumulation of osmotic regulation substances such as free proline, sugar and soluble protein facilitate plants to 1) reduce the osmotic potential, 2) to increase the solutes accumulation and tissue solute concentration, and 3) to maintain tissue turgor and tissue growth [73]. Among various organic osmotica, sugars contribute up to $50 \%$ of the total osmotic potential in glycophytes subject to saline conditions [30,36]. The major role of sugar accumulation under salt stress is osmoprotection, osmotic adjustment, carbon storage and radical scavenging [35]. Elevated sugars contents in leaf tissue have been reported in numbers of research, such as Beta vulgaris [74], Phaseolus vulgaris [75], and Lepidium crassifolium [76]. In our study, the leaf sugar content in salt-tolerant genotypes increased dramatically under higher $\mathrm{NaCl}$, which was doubled the concentration in $0.9 \%$ $\mathrm{NaCl}$ than the unsalted control (Figure 3C), while fluctuant trends were observed under different $\mathrm{NaCl}$ for the salt-sensitive genotypes. Thus, under higher $\mathrm{NaCl}$, the sugars were highly accumulated in salt-tolerant $U$. pumila than the salt-sensitive genotypes fluctuant trends under different $\mathrm{NaCl}$ fluctuant trends under different $\mathrm{NaCl}$. The similar result also reported in species such as sunflowers (Helianthus annuus) [77] and Eruca sativa [78]. The accumulated sugars content in leaves was a driving factor of survival rates of salt-tolerant genotypes under saline soil conditions such as the $0.7 \%$ and $0.9 \%$.

The accumulation of soluble protein in the tissue under saline conditions affect osmotic adjustment and provides a storage form of nitrogen re-utilized later [36]. Increasing leaf soluble proteins have been observed under salt treatment in multiple species, such as mulberry (Morus alba) [79], chick-pea (Cicer arietinum) [80], and Maize (Zea maize) [81]. Previous studies also suggested that the leaf soluble protein was highly accumulated in the salt-tolerant than in salt-sensitive cultivars of sunflower (Helianthus annuus) [77], finger millet (Eleusine coracana) [82] and rice (Oryza sativa) [83]. In contrast, the soluble protein contents declines in response to salinity, e.g., in Amaranthus tricolor [84], Raphanus sativus [85] and mangrove (Bruguiera parviflora) [86]. Yet, there were no significant differences in leaf soluble protein content between salt-tolerant and salt-sensitive plants of safflower (Carthamus tinctorius) [77] and Eruca sativa [78]. We demonstrated that an increment of soluble protein content in all $U$. pumila genotypes under elevated $\mathrm{NaCl}$ (Figure 3B); and both salt-sensitive and salt-tolerant genotypes show a similar trend of the soluble protein content in leaves tissue. The accumulation of soluble protein in $U$. pumila is an inclusive physiological reaction of salt stress. The soluble protein accumulation in the leaf tissue fails to indicate the interspecific variation of salt tolerance of $U$. pumila, even though there is a positive correlation between $\mathrm{NaCl}$ and protein accumulation.

In addition to the role of osmotic adjustment, proline can scavenge free radicals, stabilize sub-cellular structures, and buffer cellular redox potential [87]. Proline accumulates extensively in leaf tissue under salt stress in plants, e.g., sorghum (Sorghum bicolor) [88], peanut (Arachis hypogaea) [88], olive trees (Olea europaea) [89], Populus tomentosa [90], and eucalypt genotypes (Eucalyptus spp.) [27]. We found that free proline content in leaves tissue increased with an increment of $\mathrm{NaCl}$ after two months treatment. Both the saltsensitive and salt-tolerant genotypes expressed a similar trend in the change of proline content in U. pumila (Figure 3A) so that the accumulation of free proline in U. pumila is an general physiological incidence rather than the signitures due to the damage related to salt stress. Similar results were also reported in the comparative studies of sorghum (Sorghum bicolor) cultivars [31] and genotypes [91].

Salt stress also damages the chloroplast structure, reduces the chlorophyll leaf concentrations, net photosynthesis (Pn), and transpiration rate (Tr) [50]. In our study, the Pn rate and leaf chlorophyll content in $U$. pumila seedlings declined under the increasing $\mathrm{NaCl}$ (Figure 5, Figure 3D). Similar trends were reported Calligonum mongolicum [92], rice (Oryza sativa) [93] and chickpea (Cicer arietinum) [61]. In our study, both salt-tolerant and 
salt-sensitive genotypes show similar trends of change in the photosynthesis rate and leaf chlorophyll content under the salt stress without apparent differences among groups.

The change of $\operatorname{Tr}$ rate varied among different genotypes. For genotype \#6, $\operatorname{Tr}$ increased at $0.3 \%$ and $0.5 \% \mathrm{NaCl}$ and decreased at $0.7 \%$ and $0.9 \% \mathrm{NaCl}$. The Tr of \#1, \#2, and $\# 5$ seedlings increased at $0.3 \% \mathrm{NaCl}$ and decreased at $0.5 \%$ to $0.9 \% \mathrm{NaCl}$. While for the genotypes \#3, the $\mathrm{Tr}$ decreased with the increasing $\mathrm{NaCl}$. The change of $\mathrm{Tr}$ expressed no common trends between the two groups or no significant difference between salt-tolerant and salt-sensitive genotypes (Table 2).

Water use efficiency (WUE) can describe the relationship between a unit of biomass produced per unit of water used [94]. In our study, no significant differences were shown between salt-tolerance and salt-sensitive genotypes. WUE was not associated with the $\mathrm{NaCl}$. Similar results were reported in other species such as chickpea [61] that genetypic variation was expressed in terms of the WUE reaction under changing salt concentrations.

\section{Conclusions}

Salt-resistant strategies differ among plant species [36]. The comparative study of the salttolerant and sensitive species or genotypes improves the understanding of the salt-resistance behaviors and strategies during the salinity stress. The contrasting physiological changes demonstrated the specific salt-tolerant strategies given distinct SOD activities and sugar content between both three salt-tolerant $U$. pumila genotypes and three saltsensitive $U$. pumilas. The high accumulation of sugars and elevated activities of SOD enzyme in leaf tissue contribute to the osmotic adjustment and ROS scavenging system and its role in salt-tolerant $U$. pumila against the salt stress. The results in the field ex vitro were in line with the findings in previous in vitro selections.

Supplementary Materials: Table S1 Net photosynthesis rate (Pn), transpiration rate $(\mathrm{Tr})$, and water use efficiency (WUE) change in different $\mathrm{NaCl}$ concentration treatments of 6 genotypes of $U$. pumila.

Table S2. Principal component analysis (PCA) of $\mathrm{NaCl}$ treatment concentration $(\mathrm{NaC})$ and photosynthesis variables.

Author Contributions: DYM conceptualized the study, designed the methodology, and formally analyzed and visualized the data. DYM wrote the draft and edited the manuscript. CD visualized the data, reviewed and edited the drafts.

Funding: The research was funded by the World Bank loan project (Shandong Ecological Afforestation Project P112759, funding No.: SEAP-PY-3) ; Forestry Innovation Project of Agricultural Innovation Program in Shandong Province (funding No.: 2019LY005, 2019LY009).

Data Availability Statement: Data are available by contacting the authors.

Acknowledgments: We thank Dr. Wang Qiang for assisting the data analysis.

Conflicts of Interest: The authors declare no conflict of interest. 


\section{References}

1. Eliasch, J. Climate change: financing global forests: the Eliasch review; Earthscan: 2008.

2. Evans, J. Plantation forestry in the tropics: tree planting for industrial, social, environmental, and agroforestry purposes; Oxford University Press: 1992.

3. Kanninen, M. Plantation forests: global perspectives. Ecosystem goods and services from plantation forests 2010, 1-15.

4. C., O.; P.N., D. Assessing the vulnerability of urban forests to climate change. Environmental Reviews 2014, 22, 311-321, doi:10.1139/er-2013-0078.

5. Ordóñez-Barona, C.; Sabetski, V.; Millward, A.A.; Steenberg, J. De-icing salt contamination reduces urban tree performance in structural soil cells. Environmental Pollution 2018, 234, 562-571, doi:10.1016/j.envpol.2017.11.101.

6. Equiza, M.A.; Calvo-Polanco, M.; Cirelli, D.; Señorans, J.; Wartenbe, M.; Saunders, C.; Zwiazek, J.J. Long-term impact of road salt $(\mathrm{NaCl})$ on soil and urban trees in Edmonton, Canada. Urban Forestry \& Urban Greening 2017, 21, 16-28, doi:10.1016/j.ufug.2016.11.003.

7. Park, Y.-S. Conifer Somatic Embryogenesis and Multi-Varietal Forestry. In Challenges and Opportunities for the World's Forests in the 21st Century, Fenning, T., Ed. Springer Netherlands: Dordrecht, 2014; 10.1007/978-94-007-7076-8_17pp. 425-439.

8. Zhu, J.-K. Plant salt tolerance. Trends in Plant Science 2001, 6, 66-71, doi:10.1016/S1360-1385(00)01838-0.

9. Flowers, T.J.; Colmer, T.D. Salinity tolerance in halophytes. New Phytol. 2008, 179, 945-963, doi:10.1111/j.1469-8137.2008.02531.x.

10. Szabolics, I. Soils and salinization. In: Pessarakli, M. (Ed.), 1994, Handbook of Plant and Crop Stress. Marcel Dekker, New York, pp. 3-11.

11. Negrão, S.; Schmöckel, S.; Tester, M. Evaluating physiological responses of plants to salinity stress. Annals of botany 2017, 119, 1-11.

12. Zhang, J.; Xing, S.; Li, J.; Makeschin, F.; Song, Y. Agroforestry and its application in amelioration of saline soils in eastern China coastal region. For. Stud. China 2004, 6, 27-33, doi:10.1007/s11632-004-0016-2.

13. Khasa, P.D.; Hambling, B.; Kernaghan, G.; Fung, M.; Ngimbi, E. Genetic variability in salt tolerance of selected boreal woody seedlings. Forest Ecology and Management 2002, 165, 257-269, doi:10.1016/S0378-1127(01)00623-5.

14. Niknam, S.R.; McComb, J. Salt tolerance screening of selected Australian woody species - a review. Forest Ecology and Management 2000, 139, 1-19, doi:10.1016/S0378-1127(99)00334-5.

15. Bell, D.T. Australian Trees for the Rehabilitation of Waterlogged and Salinitydamaged Landscapes. Australian Journal of Botany 1999, 47, 697-716, doi:10.1071/BT96110.

16. Flowers, T.; Hajibagheri, M.; Clipson, N. Halophytes. The quarterly review of biology 1986, 61, 313-337.

17. Subbarao, G.; Wheeler, R.; Stutte, G.; Levine, L. How Far Can Sodium Substitute for Potassium in Red Beet? Journal of plant nutrition 1999, 22, 1745-1761, doi:10.1080/01904169909365751.

18. Ohshima, H.; Tang, X.; Shao, H. Physiological and Molecular Aspects of Mechanisms Involved in Plant Response to Salt Stress. In Encyclopedia of Biocolloid and Biointerface Science 2V Set, 2016; 10.1002/9781119075691.ch71pp. 870-884.

19. Abbasi, G.H.; Akhtar, J.; Ahmad, R.; Jamil, M.; Anwar-ul-Haq, M.; Ali, S.; Ijaz, M. Potassium application mitigates salt stress differentially at different growth stages in tolerant and sensitive maize hybrids. Plant Growth Regulation 2015, 76, 111-125, doi:10.1007/s10725-015-0050-1.

20. Zhu, J.-K. Abiotic Stress Signaling and Responses in Plants. Cell 2016, 167, 313324, doi:10.1016/j.cell.2016.08.029. 
21. Ahmad, P.; Abdel Latef, A.A.; Hashem, A.; Abd_Allah, E.F.; Gucel, S.; Tran, L.S.P. Nitric Oxide Mitigates Salt Stress by Regulating Levels of Osmolytes and Antioxidant Enzymes in Chickpea. Frontiers in Plant Science 2016, 7, doi:10.3389/fpls.2016.00347.

22. Flowers, T.J.; Colmer, T.D. Plant salt tolerance: adaptations in halophytes. Annals of Botany 2015, 115, 327-331, doi:10.1093/aob/mcu267.

23. Nath, M.; Bhatt, D.; Prasad, R.; Gill, S.S.; Anjum, N.A.; Tuteja, N. Reactive Oxygen Species Generation-Scavenging and Signaling during Plant-Arbuscular Mycorrhizal and Piriformospora indica Interaction under Stress Condition. Frontiers in plant science 2016, 7, 1574-1574, doi:10.3389/fpls.2016.01574.

24. Mudgal, V.; Madaan, N.; Mudgal, A. Biochemical mechanisms of salt tolerance in plants: a review. International Journal of Botany 2010, 6, 136-143.

25. Sarkar, A.; Ghosh, P.K.; Pramanik, K.; Mitra, S.; Soren, T.; Pandey, S.; Mondal, M.H.; Maiti, T.K. A halotolerant Enterobacter sp. displaying ACC deaminase activity promotes rice seedling growth under salt stress. Research in Microbiology 2018, 169, 20-32, doi:10.1016/j.resmic.2017.08.005.

26. Horie, T.; Karahara, I.; Katsuhara, M. Salinity tolerance mechanisms in glycophytes: An overview with the central focus on rice plants. Rice 2012, 5, 11, doi:10.1186/1939-8433-5-11.

27. Cha-um, S.; Somsueb, S.; Samphumphuang, T.; Kirdmanee, C. Salt-tolerant screening in eucalypt genotypes (Eucalyptus spp.) using photosynthetic abilities, proline accumulation, and growth characteristics as effective indices. In Vitro Cellular \& Developmental Biology - Plant 2013, 49, 611-619, doi:10.1007/s11627-013-9537-5.

28. Pandolfi, C.; Azzarello, E.; Mancuso, S.; Shabala, S. Acclimation improves salt stress tolerance in Zea mays plants. Journal of Plant Physiology 2016, 201, 1-8, doi:10.1016/j.jplph.2016.06.010.

29. Hanin, M.; Ebel, C.; Ngom, M.; Laplaze, L.; Masmoudi, K. New Insights on Plant Salt Tolerance Mechanisms and Their Potential Use for Breeding. Frontiers in Plant Science 2016, 7, doi:10.3389/fpls.2016.01787.

30. Ashraf, M.; Harris, P.J.C. Potential biochemical indicators of salinity tolerance in plants. Plant Science 2004, 166, 3-16, doi:10.1016/j.plantsci.2003.10.024.

31. Shakeri, E.; Emam, Y. Selectable Traits in Sorghum Genotypes for Tolerance to Salinity Stress. Journal of Agricultural Science \& Technology 2017, 19, 1319-1332.

32. Yazici, I.; Türkan, I.; Sekmen, A.H.; Demiral, T. Salinity tolerance of purslane (Portulaca oleracea L.) is achieved by enhanced antioxidative system, lower level of lipid peroxidation and proline accumulation. Environmental and Experimental Botany 2007, 61, 49-57, doi:10.1016/j.envexpbot.2007.02.010.

33. Rana, V.; Ram, S.; Nehra, K.; Sharma, I. Expression of Genes Related to Na+ Exclusion and Proline Accumulation in Tolerant and Susceptible Wheat Genotypes under Salt Stress. Cereal Research Communications 2016, 44, 404-413, doi:10.1556/0806.44.2016.009.

34. Yokota, S. Relationship between salt tolerance and proline accumulation in Australian acacia species. J For Res 2003, 8, 0089-0093, doi:10.1007/s103100300010.

35. Parida, A.K.; Das, A.B. Salt tolerance and salinity effects on plants: a review. Ecotoxicology and Environmental Safety 2005, 60, 324-349, doi:10.1016/j.ecoenv.2004.06.010.

36. Parvaiz, A.; Satyawati, S. Salt stress and phyto-biochemical responses of plants-a review. Plant Soil and Environment 2008, 54, 89.

37. Mu, D.; Zwiazek, J.; Li, Z.; Zhang, W. Genotypic variation in salt tolerance of Ulmus pumila plants obtained by shoot micropropagation. Acta Physiol Plant 2016, 38, 116.

38. Tang, Y.; Jiang, D.-M.; Lü, X.-T. Effects of Exclosure Management on Elm (Ulmus pumila) Recruitment in Horqin Sandy Land, Northeastern China. Arid Land Research and Management 2014, 28, 109-117, doi:10.1080/15324982.2013.800922. 
39. Su, H.; Li, Y.; Liu, W.; Xu, H.; Sun, O.J. Changes in water use with growth in Ulmus pumila in semiarid sandy land of northern China. Trees 2014, 28, 41-52, doi:10.1007/s00468-013-0928-3.

40. Dulamsuren, C.; Hauck, M.; Nyambayar, S.; Bader, M.; Osokhjargal, D.; Oyungerel, S.; Leuschner, C. Performance of Siberian elm (Ulmus pumila) on steppe slopes of the northern Mongolian mountain taiga: Drought stress and herbivory in mature trees. Environmental and Experimental Botany 2009, 66, 18-24, doi:10.1016/j.envexpbot.2008.12.020.

41. Zhang, M.; Wu, J.; Tang, Y. The effects of grazing on the spatial pattern of elm (Ulmus pumila L.) in the sparse woodland steppe of Horqin Sandy Land in northeastern China. Solid Earth 2016, 7, 631-637, doi:10.5194/se-7-631-2016.

42. Zalapa, J.; Brunet, J.; Guries, R. Patterns of hybridization and introgression between invasive Ulmus pumila (Ulmaceae) and native U. American journal of botany 2009, 96, 1116-1128, doi:10.3732/ajb.0800334.

43. Ghelardini, L.; Santini, A. Avoidance by early flushing: a new perspective on Dutch elm disease research. iForest - Biogeosciences and Forestry 2009, 2, 143-153, doi:10.3832/ifor0508-002.

44. Brunet, J.; Zalapa, J.; Pecori, F.; Santini, A. Hybridization and introgression between the exotic Siberian elm, Ulmus pumila, and the native Field elm, U. minor, in Italy. Biological Invasions 2013, 15, doi:10.1007/s10530-013-0486-z.

45. Büchel, K.; Fenning, T.; Gershenzon, J.; Hilker, M.; Meiners, T. Elm defence against herbivores and pathogens: morphological, chemical and molecular regulation aspects. Phytochemistry Reviews 2016, 15, 961-983, doi:10.1007/s11101-015-9442-0.

46. Hirsch, H.; Brunet, J.; Zalapa, J.E.; von Wehrden, H.; Hartmann, M.; Kleindienst, C.; Schlautman, B.; Kosman, E.; Wesche, K.; Renison, D., et al. Intra- and interspecific hybridization in invasive Siberian elm. Biological Invasions 2017, 19, 1889-1904, doi:10.1007/s10530-017-1404-6.

47. Hu, D.I.E.; Ma, G.; Wang, Q.; Yao, J.; Wang, Y.U.; Pritchard, H.W.; Wang, X. Spatial and temporal nature of reactive oxygen species production and programmed cell death in elm (Ulmus pumila L.) seeds during controlled deterioration. Plant, Cell \& Environment 2012, 35, 2045-2059, doi:10.1111/j.1365-3040.2012.02535.x.

48. Wang, Y.; Li, Y.; Xue, H.; Pritchard, H.W.; Wang, X. Reactive oxygen speciesprovoked mitochondria-dependent cell death during ageing of elm (Ulmus pumila L.) seeds. The Plant Journal 2015, 81, 438-452, doi:10.1111/tpj.12737.

49. Li, Y.; Wang, Y.; Xue, H.; Pritchard, H.W.; Wang, X. Changes in the mitochondrial protein profile due to ROS eruption during ageing of elm (Ulmus pumila L.) seeds. Plant Physiol Biochem 2017, 114, 72-87, doi:10.1016/j.plaphy.2017.02.023.

50. Feng, Z.T.; Deng, Y.Q.; Fan, H.; Sun, Q.J.; Sui, N.; Wang, B.S. Effects of $\mathrm{NaCl}$ stress on the growth and photosynthetic characteristics of Ulmus pumila L. seedlings in sand culture. Photosynthetica 2014, 52, 313-320, doi:10.1007/s11099-014-0032-y.

51. Song, F.-n.; Yang, C.-p.; Liu, X.-m.; Li, G.-b. Effect of salt stress on activity of superoxide dismutase (SOD) in Ulmus pumila L. Journal of Forestry Research 2006, 17, 13-16, doi:10.1007/s11676-006-0003-7.

52. Calvo-Polanco, M.; Jones, M.D.; Zwiazek, J.J. Effects of pH on $\mathrm{NaCl}$ tolerance of American elm (Ulmus americana) seedlings inoculated with Hebeloma crustuliniforme and Laccaria bicolor. Acta Physiol Plant 2009, 31, 515-522, doi:10.1007/s11738-008-0260-5.

53. Bates, L.S.; Waldren, R.P.; Teare, I.D. Rapid determination of free proline for water-stress studies. Plant and Soil 1973, 39, 205-207, doi:10.1007/BF00018060.

54. Arnon, D.I. Copper enzymes in isolated chloroplasts. Polyphenoloxidase in Beta vulgaris. Plant Physiology 1949, 24, 1-15, doi:10.1104/pp.24.1.1.

55. Bradford, M.M. A rapid and sensitive method for the quantitation of microgram quantities of protein utilizing the principle of protein-dye binding. Analytical Biochemistry 1976, 72, 248-254, doi:10.1016/0003-2697(76)90527-3.

56. Sadasivam S, M.A. Biochemical methods (revised second edition); New Age International: New Delhi, 1996. 
57. Beauchamp, C.; Fridovich, I. Superoxide dismutase: Improved assays and an assay applicable to acrylamide gels. Analytical Biochemistry 1971, 44, 276-287, doi:10.1016/0003-2697(71)90370-8.

58. Dhindsa, R.S.; Matowe, W. Drought tolerance in two mosses: correlated with enzymatic defence against lipid peroxidation. Journal of experimental botany 1981, 32, 7991.

59. Civello, P.M.; Martinez, G.A.; Chaves, A.R.; Anon, M.C. Peroxidase from Strawberry Fruit (Fragaria ananassa Duch.): Partial Purification and Determination of Some Properties. Journal of Agricultural and Food Chemistry 1995, 43, 2596-2601, doi:10.1021/jf00058a008.

60. Aebi, H. [13] Catalase in vitro. In Methods in enzymology, Elsevier: 1984; Vol. 105, pp. 121-126.

61. Khan, H.A.; Siddique, K.H.M.; Munir, R.; Colmer, T.D. Salt sensitivity in chickpea: Growth, photosynthesis, seed yield components and tissue ion regulation in contrasting genotypes. Journal of Plant Physiology 2015, 182, 1-12, doi:10.1016/j.jplph.2015.05.002.

62. , R.D.C.T. R: A Language and Environment for Statistical Computing. . R Foundation for Statistical Computing, Vienna, Austria. R Foundation for Statistical Computing, Vienna. 2014.

63. Saied, A.S.; Keutgen, A.J.; Noga, G. The influence of $\mathrm{NaCl}$ salinity on growth, yield and fruit quality of strawberry cvs. 'Elsanta' and 'Korona'. Sci Hortic-Amsterdam 2005, 103, 289-303, doi:10.1016/j.scienta.2004.06.015.

64. Apel, K.; Hirt, H. Reactive oxygen species: metabolism, oxidative stress, and signal transduction. Annu Rev Plant Biol 2004, 55, 373-399, doi:10.1146/annurev.arplant.55.031903.141701.

65. Zhang, H.; Han, B.; Wang, T.; Chen, S.; Li, H.; Zhang, Y.; Dai, S. Mechanisms of Plant Salt Response: Insights from Proteomics. Journal of Proteome Research 2012, 11, 49-67, doi:10.1021/pr200861w.

66. Hu, L.X.; Li, H.Y.; Pang, H.C.; Fu, J.M. Responses of antioxidant gene, protein and enzymes to salinity stress in two genotypes of perennial ryegrass (Lolium perenne) differing in salt tolerance. Journal of Plant Physiology 2012, 169, 146-156, doi:10.1016/j.jplph.2011.08.020.

67. Khaliq, A.; Zia-ul-Haq, M.; Ali, F.; Aslam, F.; Matloob, A.; Navab, A.; Hussain, S. Salinity Tolerance in Wheat Cultivars Is Related to Enhanced Activities of Enzymatic Antioxidants and Reduced Lipid Peroxidation. Clean-Soil Air Water 2015, 43, 1248-1258, doi:10.1002/clen.201400854.

68. de Azevedo Neto, A.D.; Prisco, J.T.; Enéas-Filho, J.; Abreu, C.E.B.d.; GomesFilho, E. Effect of salt stress on antioxidative enzymes and lipid peroxidation in leaves and roots of salt-tolerant and salt-sensitive maize genotypes. Environmental and Experimental Botany 2006, 56, 87-94, doi:10.1016/j.envexpbot.2005.01.008.

69. Das, K.; Roychoudhury, A. Reactive oxygen species (ROS) and response of antioxidants as ROS-scavengers during environmental stress in plants. Frontiers in Environmental Science 2014, 2, doi:10.3389/fenvs.2014.00053.

70. Amor, N.B.; Jiménez, A.; Megdiche, W.; Lundqvist, M.; Sevilla, F.; Abdelly, C. Response of antioxidant systems to $\mathrm{NaCl}$ stress in the halophyte Cakile maritima. Physiologia Plantarum 2006, 126, 446-457, doi:10.1111/j.1399-3054.2006.00620.x.

71. Amirjani, M. Effect of salinity stress on growth, mineral composition, proline content, antioxidant enzymes of soybean. American Journal of Plant Physiology 2010, 5 , 350-360.

72. K, A. The water-water cycle in chloroplasts: scavenging of active oxygens and dissipation of excess photons. Annual review of plant biology 1999, 50, 601- 639.

73. De Costa, W.; Zörb, C.; Hartung, W.; Schubert, S. Salt resistance is determined by osmotic adjustment and abscisic acid in newly developed maize hybrids in the first phase of salt stress. Physiologia Plantarum 2007, 131, 311-321, doi:10.1111/j.13993054.2007.00962.x. 
74. Wang, Y.G.; Stevanato, P.; Yu, L.H.; Zhao, H.J.; Sun, X.W.; Sun, F.; Li, J.; Geng, G. The physiological and metabolic changes in sugar beet seedlings under different levels of salt stress. J Plant Res 2017, 130, 1079-1093, doi:10.1007/s10265-017-0964-y.

75. Farhangi-Abriz, S.; Torabian, S. Antioxidant enzyme and osmotic adjustment changes in bean seedlings as affected by biochar under salt stress. Ecotoxicol Environ Saf 2017, 137, 64-70, doi:10.1016/j.ecoenv.2016.11.029.

76. Murakeözy, É.P.; Nagy, Z.; Duhazé, C.; Bouchereau, A.; Tuba, Z. Seasonal changes in the levels of compatible osmolytes in three halophytic species of inland saline vegetation in Hungary. Journal of Plant Physiology 2003, 160, 395-401, doi:10.1078/01761617-00790.

77. Ashraf, M.; Fatima, H. Responses of salt-tolerant and salt-sensitive lines of safflower (Carthamus tinctorius L.) to salt stress. Acta Physiol Plant 1995, 17, 61-70.

78. Ashraf, M. Organic substances responsible for salt tolerance inEruca sativa. Biologia Plantarum 1994, 36, 255-259, doi:10.1007/BF02921095.

79. Agastian, P.; Kingsley, S.J.; Vivekanandan, M. Effect of Salinity on Photosynthesis and Biochemical Characteristics in Mulberry Genotypes. Photosynthetica 2000, 38, 287-290, doi:10.1023/A:1007266932623.

80. Soussi, M.; Ocaña, A.; Lluch, C. Effects of salt stress on growth, photosynthesis and nitrogen fixation in chick-pea (Cicer arietinum L.). Journal of Experimental Botany 1998, 49, 1329-1337.

81. El-Khallal, S.M.; Hathout, T.A.; Ahsour, A.; Kerrit, A.-A.A. Brassinolide and salicylic acid induced antioxidant enzymes, hormonal balance and protein profile of maize plants grown under salt stress. Research Journal of Agriculture and Biological Sciences 2009, 5, 391-402.

82. Uma, S.; Prasad, T.; Kumar, M.U. Genetic variability in recovery growth and synthesis of stress proteins in response to polyethylene glycol and salt stress in finger millet. Annals of Botany 1995, 76, 43-49.

83. Lutts, S.; Kinet, J.; Bouharmont, J. Effects of salt stress on growth, mineral nutrition and proline accumulation in relation to osmotic adjustment in rice (Oryza sativa L.) cultivars differing in salinity resistance. Plant growth regulation 1996, 19, 207-218.

84. Wang, Y.; Nii, N. Changes in chlorophyll, ribulose bisphosphate carboxylaseoxygenase, glycine betaine content, photosynthesis and transpiration in Amaranthus tricolor leaves during salt stress. The Journal of Horticultural Science and Biotechnology 2000, 75, 623-627.

85. Muthukumarasamy, M.; Gupta, S.D.; Panneerselvam, R. Enhancement of peroxidase, polyphenol oxidase and superoxide dismutase activities by triadimefon in $\mathrm{NaCl}$ stressed Raphanus sativus L. Biologia Plantarum 2000, 43, 317-320.

86. Parida, A.; Das, A.B.; Das, P. $\mathrm{NaCl}$ stress causes changes in photosynthetic pigments, proteins, and other metabolic components in the leaves of a true mangrove, Bruguiera parviflora, in hydroponic cultures. Journal of Plant Biology 2002, 45, 28-36.

87. Ashraf, M.; Foolad, M.R. Roles of glycine betaine and proline in improving plant abiotic stress resistance. Environmental and experimental botany 2007, 59, 206-216.

88. Surender Reddy, P.; Jogeswar, G.; Rasineni, G.K.; Maheswari, M.; Reddy, A.R.; Varshney, R.K.; Kavi Kishor, P.B. Proline over-accumulation alleviates salt stress and protects photosynthetic and antioxidant enzyme activities in transgenic sorghum [Sorghum bicolor (L.) Moench]. Plant Physiology and Biochemistry 2015, 94, 104-113, doi:10.1016/j.plaphy.2015.05.014.

89. Ahmed, C.; Rouina, B.; Sensoy, S.; Boukhriss, M.; Abdullah, F. Exogenous Proline Effects on Photosynthetic Performance and Antioxidant Defense System of Young Olive Tree. Journal of agricultural and food chemistry 2010, 58, 4216-4222, doi:10.1021/jf9041479.

90. Du, N.; Liu, X.; Li, Y.; Chen, S.; Zhang, J.; Ha, D.; Deng, W.; Sun, C.; Zhang, Y.; Pijut, P.M. Genetic transformation of Populus tomentosa to improve salt tolerance. Plant Cell, Tissue and Organ Culture (PCTOC) 2012, 108, 181-189, doi:10.1007/s11240-011-00264. 
91. de Lacerda, C.F.; Cambraia, J.; Oliva, M.A.; Ruiz, H.A.; Prisco, J.T. Solute accumulation and distribution during shoot and leaf development in two sorghum genotypes under salt stress. Environmental and Experimental Botany 2003, 49, 107-120, doi 10.1016/S0098-8472(02)00064-3.

92. Xu, D.; Wang, W.; Gao, T.; Fang, X.; Gao, X.; Li, J.; Bu, H.; Mu, J. Calcium alleviates decreases in photosynthesis under salt stress by enhancing antioxidant metabolism and adjusting solute accumulation in Calligonum mongolicum. Conservation Physiology 2017, 5, doi:10.1093/conphys/cox060.

93. Wang, X.; Xiong, D. Diffusional conductance to CO2 is the key limitation to photosynthesis in salt-stressed leaves of rice (Oryza sativa L.); 2017.

94. Sun, Z.W.; Ren, L.K.; Fan, J.W.; Li, Q.; Wang, K.J.; Guo, M.M.; Wang, L.; Li, J.; Zhang, G.X.; Yang, Z.Y., et al. Salt response of photosynthetic electron transport system in wheat cultivars with contrasting tolerance. Plant Soil and Environment 2016, 62, 515521, doi:10.17221/529/2016-Pse. 